\title{
Between Diplomacy and Paradiplomacy: Taiwan's Foreign Relations in Current Practice
}

\section{Erik Pajtinka}

Matej Bel University

\begin{abstract}
The study deals with Taiwan's engagement in international relations from the viewpoint of practical performance of its foreign activities. It is stressed that Taiwan's foreign activities may be divided by their nature into two basic groups: the official diplomatic activities that Taiwan carries out in relation to those foreign states with which it has established diplomatic relations, and unofficial quasidiplomatic or paradiplomatic activities that Taiwan carries out in relation to the states with which it does not have diplomatic relations. In the study, the diplomatic and quasidiplomatic or paradiplomatic activities of Taiwan are compared, especially with emphasis on their institutional backgrounds, legal regulations, and other conditions for their practical performance. It is concluded that the differences between the diplomatic and paradiplomatic dimensions of Taiwan's foreign activities are rooted mainly in their formal and protocolar aspects, whereas from the viewpoint of their organization and practical performance, these differences are minimal.
\end{abstract}

\section{Keywords}

diplomacy of Taiwan; paradiplomacy; unofficial communication among states; representative offices

\section{Introduction}

As is widely known, the status of the Republic of China, or for short Taiwan, is currently perceived in various ways by individual members of the international community. For most of the states of the world who maintain diplomatic relations with the government of the People's Republic of China (PRC), Taiwan is formally considered a "province", i.e., a nonsovereign substate unit within the PRC. ' On the contrary, for a smaller number of countries, which do not have diplomatic relations with the Beijing government, Taiwan is a sovereign "state". This special "twofold" status of Taiwan is also reflected in the existence of two types of foreign activity carried out by Taiwan, which

\footnotetext{
* Erik Pajtinka, Matej Bel University, Faculty of Political Science and International Relations, Department of International Relations and Diplomacy, Kuzmanyho 1, SK-974 01 Banska Bystrica, Slovakia; erik.pajtinka@umb.sk.

1 From the theoretical point of view, Taiwan probably cannot be seen as a "typical" province, but rather, it is an entity sui generis.
} 
differ from each other in their character. These include, on the one hand, "standard" official diplomatic activities, which Taiwan performs as a state (in relation to other states with which it has established diplomatic relations), and on the other, the unofficial quasidiplomatic, or rather paradiplomatic, activities that Taiwan performs as a province (in relation to the states with which it does not have established diplomatic relations).

On the whole, a sufficient quantity of contemporary academic literature in the field of international relations is dedicated to the issue of Taiwan's foreign relations ${ }^{2}$. However, the overwhelming majority of these works deal mainly with Taiwan's foreign policy and its particular thematic or territorial focus or the development of Taiwan's external priorities and relations with other states; that is, they generally study Taiwan's foreign relations, mostly from the viewpoint of their content. On the contrary, only a very few works deal with Taiwan's foreign relations from the viewpoint of the practical techniques and forms used, i.e., from the viewpoint of diplomatic theory. It is our ambition to at least partly fill this notional gap with this work.

In the first section of this work, dedicated to the theoretical definition of diplomacy and paradiplomacy, we could draw on a rather wide range of various specialist works, from which we especially used monographs, as well as encyclopedic works and studies, by renowned Slovak, Czech, and particularly foreign authors specializing in the field of diplomacy. However, for the other sections of the work, where we specifically dealt with the issues of the practical performance of Taiwan's foreign activities, due to the previously mentioned lack of academic literature on this topic, we also had to draw information from other sources, along with the few relevant academic studies. Among those were official documents, especially the website of the Ministry of Foreign Affairs of the Republic of China (Taiwan), Taiwan's foreign representations, and diplomatic missions of other states. Extraordinarily valuable information was provided through personal communication with the staff of various diplomatic bodies (e.g., Embassy of the Federal Republic of Germany in the Slovak Republic) and foreign representations of Taiwan (e.g., Taipei Representative Office in Bratislava).

The purpose of this study is to familiarize the reader with the specific character of Taiwan's activities in international relations from the viewpoint of the practical performance of its foreign activities. At the same time, it also aims to compare the diplomatic and quasidiplomatic or paradiplomatic activities

\footnotetext{
2 For example, in Scopus database, we can find approximately twenty studies, books and book chapters published in the last five years which are dealing (based on abstracts and key words) with various issues and questions of Taiwan's foreing policy.
} 
of Taiwan, especially with emphasis on their institutional backgrounds, legal regulations, and other conditions for their practical performance.

Given the fact that the notions of diplomacy and paradiplomacy, with which we are going to work, are in the contemporary theory of international relations interpreted in diverse ways and used in different contexts, the first section of this study will be dedicated to a brief definition of both these notions and, subsequently, to the explanation of their usage in relation to the foreign activities of Taiwan. In the second section of the study, we shall briefly outline the beginnings of Taiwan's foreign activities and the unique circumstances of its entry onto the international political scene, which are closely related to the specific character of its current foreign activities. In the third section, we shall deal with the description and analysis of the particular forms of Taiwan's foreign activities, with emphasis on their institutional background, organization, legal regulation, and other practical aspects of their performance. As this study focuses primarily on the questions of the practical performance of Taiwan's foreign activities, other questions related to this issue, such as Taiwan's international legal status or the definition of the notion of sovereignty, will not be the objects of more detailed scrutiny. Nor will Taiwan's activities in relation to continental China (PRC) be the object of deeper scrutiny, as, although they can also be considered a certain type of "external" activity, given their specific character, they would require a more comprehensive analysis.

\section{Definition of the Terms Diplomacy and Paradiplomacy}

The terms "diplomacy" and "paradiplomacy" in contemporary academic sources are used with several relatively different meanings, which is why it is necessary to at least briefly explain them.

The notion of "diplomacy" in its modern sense, as the administration of international affairs through negotiations, first came to be used in the eighteenth century. At the time, the term "diplomacy" was associated almost exclusively with the state. It was only in the course of the twentieth century that the use of the term diplomacy also spread to the activities of international intergovernmental organizations, and currently, this word is sometimes even used in regard to the involvement of various other nongovernmental entities, such as supranational corporations, in international relations. Here, it is necessary to remark that the use of the term diplomacy in relation to activities of entities other than the state is not accepted universally in contemporary academic sources or in diplomatic practice. Among nonstate actors, a relatively wide level of acceptance of the word "diplomacy" may 
probably only be observed in relation to international intergovernmental organizations, and also perhaps the Holy See. It is possible to theoretically justify the use of this term in relation to the external activities of international intergovernmental organizations by the fact that the activities of international intergovernmental organizations in international relations just represent a different, mediated form of promotion of states' foreign policy interests. It is possible to confirm this by considering that international intergovernmental organizations serve their member states and are founded for carrying out their member states' joint interests. ${ }^{3}$ As far as the use of the notion of diplomacy in relation to the foreign activities of the Holy See is concerned, this could be "justified" by the unprecedented long-term historical tradition of the Holy See's diplomatic activities.

When defining the term diplomacy in this study, we shall base it on its "traditional" and, at the same time, the most universally accepted use, i.e., we shall define it in relation to the state. As far as we associate the notion of diplomacy with the state, we can distinguish several of its basic meanings.

In academic sources, as well as in diplomatic practice, the word "diplomacy" is most commonly understood as the tool or process for the promotion of a state's foreign policy interests through negotiation or other nonviolent means (with the exception of the means of international law). ${ }^{4}$ For example, distinguished British scholar and one of the world's leading experts on diplomacy, Berridge $(2010,1)$, sees diplomacy as an "activity of the state the purpose of which is to ensure the achievement of foreign policy goals without the use of force, propaganda or law". Similarly, Czech scholar and former diplomat, Hubinger $(2006,42)$, defines diplomacy as a "set of partly formalized" peaceful (nonviolent) "means and activities of governmental institutions and individuals the goal of which is to perform the state's foreign policy". For Slovak expert on diplomacy Tóth (2008, 13), too, diplomacy is the "activity of the state authorities for international relations and their representatives in the representation of the state abroad whose goal is to perform its foreign policy through negotiations and other legitimate (lawful) means". Finally, e. g., German scholar and former diplomat Kleiner $(2010,1)$ sees diplomacy as a tool of the performance of the state's foreign policy, based on communication. In this study, the term diplomacy will

\footnotetext{
3 In connection with the international organizations' right of active legation, Rosputinský $(2015,99)$ correctly remarks that the primary purpose of the work of an international organization with respect to external actors is not the promotion of its own interests, but the achievement of the joint interests of its member states.

4 Methods of international law, including, e.g., solving of disputes before an international court, are - as a rule - considered a separate tool of performance of the state's foreign policy.
} 
be understood in accordance with the above-mentioned definitions, i.e., as the sum of all those official activities of the state that are focused on the promotion of its foreign policy interests by nonviolent means (with the exception of the international law means).

It is important to know, however, that there are also other "state-related" meanings of the term diplomacy in the present international relations theory. For example, the term diplomacy is sometimes used also as a synonym for the state's foreign policy itself. It needs to be said, however, that such an interpretation of diplomacy does not appear to be very suitable, because, as correctly noted by G. R. Berridge and A. James (2003, 70), it results in the blurring of the important difference between the content of the foreign policy goals of the state (foreign policy) and the form of the promotion of these goals (diplomacy), while diplomacy, as P. Widmer $(2014,26)$ emphasized in this context, is only one of several tools that the state may use to promote its foreign policy goals. In another sense, in some cases, the term diplomacy also means the whole complex of international political interactions between states over a certain period of time and/or geographical region or even international relations as a whole (Veselý 2014, 9). In some sources, we can also find the use of the term diplomacy in the sense of the Foreign Service, i.e., the diplomatic apparatus of the state and its diplomatic activity (see, e.g., Widmer 2014, 25).

The term "paradiplomacy" began to be used in political science terminology in the second half of the 1980s as a denomination for - in that time, dynamically developing - activities of substate (regional) administrative entities in the international political arena (e.g., Aguirre 1999, 185; Kuznetsov 2015, 27). It is also in this sense that the notion of paradiplomacy is mostly used today, but its precise, more particular definition varies slightly across individual academic sources. In this regard, we can remark that in some parts of academic literature, the notion of paradiplomacy is exclusively connected with the foreign activities of regional administrative units of a "higher level", such as provinces, federal republics, and counties or states of a federation (see, e.g., Wolff 2007), while in other parts of the academic literature, paradiplomacy is associated with foreign activities of all substate administrative units, i.e., not only regional units of a "higher level” but also cities and villages (e.g., Duchacek 1990; Drulák et al. 2004; Kleiner 2010). Similarly, we can also find various interpretations of the term paradiplomacy as far as the target subjects are concerned, in relation to whom these activities may be carried out. While in a part of the academic sources, paradiplomacy only covers the activities of substate units carried 
out in relation to analogous (substate) actors abroad (e.g., Hubinger 2006), in other works, the term paradiplomacy includes also the foreign activities of substate units, carried out in relation to foreign states, i.e., toward central governments (e.g., Duchacek 1988).

The term paradiplomacy, thus, could be generally defined as a set of foreign activities of a nonsovereign substate regional unit, which are carried out with the goal of promoting the latter's interests in relation to other, analogous substate entities abroad, as well as in relation to foreign states and international organizations. ${ }^{5}$

If we take the above-mentioned definitions of diplomacy and paradiplomacy as our point of departure, we can say that foreign activities of Taiwan display, dependent on the conditions of their performance, characteristic features of both. When Taiwan carries out foreign activities in relation to foreign states with which it has diplomatic relations, it can, in the performance thereof, act as a sovereign state, and in such a case, its foreign activities may be designated as diplomatic. On the contrary, when Taiwan carries out foreign activities in relation to foreign states with which it does not have diplomatic relations (because these states maintain diplomatic relations with the PRC), it formally acts in their performance as only a province of the PRC, i.e., a nonsovereign substate unit; in such a case, we may designate these foreign activities as paradiplomatic.

\section{The Specific Circumstances of Taiwan's Entry into the International Political Arena}

In order to understand the peculiar contemporary character of Taiwan's foreign activities, it is first necessary, at least briefly, to elucidate the specifics of Taiwan's entrance onto the international political scene.

We can speak about the beginnings of Taiwan's activities as an actor in international relations from the time when, after the communists' victory in the Chinese Civil War, the PRC was declared in 1949. The government of the Republic of China then left the continental part of China, controlled by communists, for the island of Taiwan, which remained (together with several smaller nearby islands) the only territory under its control. Simultaneously, even after the transfer to Taiwan, the government of the Republic of China continued to fulfill its normal executive role, which

\footnotetext{
5 We would like to add that in a smaller part of specialist literature also, some other designations tend to be used as an equivalent of the term paradiplomacy, such as substate diplomacy (e.g., Criekemans 2010) or constituent diplomacy (e.g., McMillan 2012). In our study, we have decided to use the term paradiplomacy, as this is the most widely established term in the contemporary academic literature.
} 
also included the maintenance of official diplomatic contacts with foreign states and participation in activities within international intergovernmental organizations, including, e.g., the UN. Understandably, the new communist government of the PRC in Beijing started to make an effort to establish diplomatic contacts of its own and, furthermore, it began to make clear to foreign governments that it considered itself "the sole legal government representing all the people" (Proclamation of the Central People's Government of the PRC 1986) of China. It was an unequivocal message to the governments of foreign states that they had to choose whether to maintain official diplomatic relations with the PRC government in Beijing or with the government of the Republic of China in Taiwan. In diplomatic practice, this meant that when establishing diplomatic relations with any foreign state, the PRC insisted that this state cut off or/and will not establish "parallel" diplomatic relations with the Republic of China in Taiwan. Several states that had established diplomatic relations with the PRC - and consequently could not maintain diplomatic relations with Taiwan - at least wanted to also maintain a certain form of nondiplomatic contact with the Taipei government. This was especially due to pragmatic reasons, as this government effectively controlled the whole territory of the island of Taiwan. For example, Great Britain, which was the first among the "Western" powers to establish diplomatic relations with the PRC in 1950 , continued to maintain consular relations ${ }^{6}$ with Taiwan through its consulate in the city of Tamsui after it cut off diplomatic relations with the government of the Republic of China. Nevertheless, this form of nondiplomatic contact between Taiwan and Great Britain only lasted until 1972, when Great Britain, due to an increase in the level of its diplomatic representation in the PRC, closed down the consulate in Tamsui and thus definitively discontinued any official relations with Taiwan. ${ }^{7}$ In most other cases, the states that established diplomatic relations with the PRC had from the beginning maintained only unofficial (nondiplomatic and nonconsular) contacts with Taiwan, within which Taiwan formally acted not as a state, but as a province of the PRC. These contacts became the basis for the

6 Consular relations are a specific type of relations among states that can be established and/or maintained independently from the existence or nonexistence of diplomatic relations between them. Thus, consular relations can be regarded as a kind of essentially nondiplomatic relations.

7 In a joint communiqué of the governments of Great Britain and the PRC of March 13, 1972, Great Britain, "acknowledging the position of the Chinese Government that Taiwan is the province of the People's Republic of China“, undertook to close down its consulate in Tamsui in Taiwan as of March 13, 1972 (Joint Communiqué of the Governments of the United Kingdom, 2004). 
unofficial, paradiplomatic dimension of Taiwan's foreign activities, existing alongside their official, diplomatic dimension. ${ }^{8}$

In 1949, when Taiwan entered the international political arena, most of its foreign activities had an official, diplomatic character. In the following period, however, the number of states that had established diplomatic relations with the PRC and thus terminated diplomatic contacts with the Taipei government gradually grew, as a result of which gradually more and more Taiwan's foreign activities acquired a nondiplomatic character. A substantial breakthrough in this developmental trend occurred in 1971 when the PRC assumed Taiwan's seat in the UN. A number of states that had until then maintained diplomatic relations with Taipei reacted to this event by establishing diplomatic relations with Beijing. As an illustration, whereas in 1971, Taiwan had diplomatic relations with 68 countries and the PRC with only 53 countries, in 1979, this ratio was already markedly opposite, with only 21 states maintaining diplomatic relations with Taiwan and as many as 117 states with the PRC (Rawnsley 2000, 16).

\section{Diplomatic and Paradiplomatic Dimension of Taiwan's Foreign Activities}

As we have already stated, Taiwan's foreign activities may be divided by their nature into two basic groups: the official diplomatic activities, which Taiwan carries out in relation to those foreign states with which it has established diplomatic relations; and the unofficial paradiplomatic activities, which Taiwan carries out in relation to the states with which it does not have diplomatic relations. Besides these two categories of Taiwan's foreign activities, we can also distinguish a special category of unofficial external activities that Taiwan performs within the so-called Cross-Strait Relations with continental China, i.e., with authorities from the PRC.

To carry out diplomatic activities, Taiwan uses ${ }^{9}$ a network of 20 diplomatic missions formed exclusively as embassies, ${ }^{10}$ with the exception of a single

\footnotetext{
8 It is necessary to say that not only Taiwan but also the PRC, in the beginning, also carried out, alongside official diplomatic activities, unofficial external ones. In this respect, e.g., the PRC had, as early as 1973, established in the USA its informal representation, the Liaison Office (Kočnerová and Marenčáková 2014, 5), which provided unofficial contacts with the Washington government.

9 As of December 31, 2016.

10 Taiwan's embassies are located especially in the states of North and South America (Belize, Guatemala, Honduras, Nicaragua, Panama, Paraguay, and El Salvador), the Caribbean (Dominican Republic, Haiti, Saint Lucia, Saint Christopher and Nevis, as well as Saint Vincent and the Grenadines), and the Oceania (Kiribati, Marshall Islands, Nauru, Solomon Islands, Tuvalu); a small number of them are also located in the states of Africa (Burkina Faso and Swaziland). The only embassy of Taiwan in Europe is at the Holy See in Rome.
} 
consular office, that being a consulate general ${ }^{11}$ (Ministry of Foreign Affairs, Republic of China, ROC Embassies, 2016). All these representations of Taiwan act under the official name of the Embassy of the Republic of China (or the Consulate General of the Republic of China), i.e., under the designation that is commonly used for this type of office in the diplomatic practice of other states. Unlike diplomatic missions of most other states, however, the provisions of the Vienna Convention on Diplomatic Relations do not apply to the diplomatic missions of Taiwan and their staff, as Taiwan is not a party to this international treaty. Despite that, in practice, there are not, at least outwardly, almost any visible differences between the diplomatic missions of Taiwan and the states that are parties to the Vienna Convention on Diplomatic Relations. For example, the heads of the diplomatic missions (embassies) of Taiwan are officially addressed as Ambassador Extraordinary and Plenipotentiary, they submit their credentials to the head of the host state when they come into office, and within the diplomatic corps of the state in which they are accredited, they are granted a protocolar order of precedence according to the same principles as the heads of diplomatic missions of other states.

Besides diplomatic missions and the consular office, one permanent mission that participates in the performance of Taiwan's diplomatic activities is established at the World Trade Organization (WTO) in Geneva with the official name of the "Permanent Mission of the Separate Customs Territory of Taiwan, Penghu, Kinmen and Matsu to the WTO”. Despite the specific name - based on the designation under which Taiwan officially acts ${ }^{12}$ in the WTO - this Taiwanese permanent mission, from the viewpoint of international law and protocolar standing, does not differ at all from other permanent missions that are established at this international organization by its individual member states. For example, the official title of the head of the Taiwanese permanent mission at the WTO is "permanent representative", which is the same as the other heads of permanent missions accredited at the WTO. The procedural protocol applied when welcoming a head of the mission into office is also identical, including the solemn submission of credentials to the secretary general of the WTO (Permanent Mission, 2016).

To carry out quasidiplomatic or paradiplomatic activities, Taiwan has a network of 92 unofficial (nondiplomatic and nonconsular) foreign

11 The only consulate general of Taiwan is located in the city Ciudad del Este in Paraguay.

12 Taiwan was accepted as a member of the WTO under the name of Separate Customs Territory of Taiwan, Penghu, Kinmen and Matsu (shortly, Chinese Taipei) (World Trade Organization, 2017), and it also operates in this international organization under this name. 
representations available, ${ }^{13}$ of which 58 belong to the category of representative offices and 34 are ranked as offices (Ministry of Foreign Affairs, Republic of China 2016). The basic difference between these two categories of Taiwan's foreign representations is that the representative offices are established in the capital cities of the host states and are headed by a "representative", while offices are based outside the capitals and the head is officially addressed as "director-general". From the organizational and formal point of view, offices act as "branches" of the representative office in the respective host state. If we were to compare them to the usual types of diplomatic and consular representations of states, it would be possible to consider representative offices as analogous to diplomatic missions, ${ }^{14}$ while offices could be perceived as analogous to consular offices ${ }^{15}$ (from which the offices in some cases were actually created). ${ }^{16}$

The official designation of the informal foreign representations of Taiwan, of both the representative offices and offices, varies in practice. It differs depending on the particular host state as well as from case to case. Currently, the unofficial representations of Taiwan act under as many as 16 various official names throughout the world; most frequently, they are known as "Taipei Economic and Cultural Office" ${ }^{17}$ and "Taipei Representative Office". 18 These, as well as all the other official names of Taiwan's representations (the complete list can be found in Table 1), are used regardless of the category of the particular unofficial representation. For example, all three of the representations of Taiwan in Canada - in the capital Ottawa, as well as in the cities of Toronto and Vancouver - are officially administratively designated as

13 As of December 31, 2016.

14 In support of this statement, we may add that, e.g., according to the website of Taipei Economic and Cultural Office in New Zealand's Wellington, which is one of Taiwan's representative offices, this (office) has "the same function as an embassy" (Taipei Economic and Cultural Office in New Zealand 2017).

15 The comparison of offices to consular offices can also be found on the official websites of some of these representations. For example, on the website of the office in München (Taipeh Vertretung in der Bundesrepublik Deutschland -Buero Munchen) and in Auckland (Taipei Economic and Cultural Office in Auckland), it is stated that this (office) functions as a "de facto consulate general" (Taipeh Vertretung in der Bundesrepublik, 2015) and that "it fulfils the same function as a consulate general" (Taipei Economic and Cultural Office in Auckland, 2016).

16 Namely, e.g., Taipei Economic and Cultural Office in Chicago (USA) acted until 1994 under the name of Coordination Council for North American Affairs in Chicago, which originated from the transformation of a Consulate General of the Republic of China in Chicago, which occurred after the establishment of diplomatic relations between the USA and the PRC in 1979 (Taipei Economic and Cultural Office in Chicago, 2016).

17 Almost half of all the representations in the world, including, e.g., representation in the Czech Republic.

18 More than 10 representations mostly in Europe, including, e.g., representation in the Slovak Republic. 
Taipei Economic and Cultural Office. Similarly, all four of the representations of Taiwan in Australia - in the capital Canberra, as well as in the cities of Brisbane, Melbourne, and Sydney - act under the official name of Taipei Economic and Cultural Office. The only exceptions today in this respect are the representations of Taiwan in the USA. In the case of the principal representation in Washington, the designation "Taipei Economic and Cultural Representative Office" is used. A different designation is then used for the other representations in other cities in the USA, which are officially known as "Taipei Economic and Cultural Offices". 19

Table 1: Names used by unofficial representations of Taiwan in the world (in alphabetical order)

\begin{tabular}{|l|}
\hline Commercial Office of Taipei \\
\hline Commercial Office of the Republic of China \\
\hline Economic and Cultural Delegation of Taipei \\
\hline Representative Office \\
\hline Taipei Commercial Representative Office \\
\hline Taipei Economic and Cultural Center \\
\hline Taipei Economic and Cultural Mission \\
\hline Taipei Economic and Cultural Office \\
\hline Taipei Economic and Cultural Representative Office \\
\hline Taipei Economic and Trade Office \\
\hline Taipei Liaison Office \\
\hline Taipei Mission \\
\hline Taipei Representation \\
\hline Taipei Representative Office \\
\hline Taipei Trade and Economic Representative Office \\
\hline Trade Mission of the Republic of China \\
\hline
\end{tabular}

All the unofficial foreign representations of Taiwan, regardless of their category, basically have a similar organizational structure, which - to a great extent - resembles the organizational structure of diplomatic missions or consular offices. At most of the representations of Taiwan, we can find, e.g., a section of economic and commercial cooperation, a section for cultural cooperation, and a consular section with the visa department, or a department that provides assistance to citizens, which likewise mostly form a common part of the organizational structure of diplomatic missions or consular offices. On the other hand, a political section, which is a fundamental part of the

19 The official designations of Taiwan's representations in the USA are laid down in the Agreement on Privileges, Exemptions and Immunities between the American Institute in Taiwan and the Taipei Economic and Cultural Representative Office in the United States of February 4, 2013. 
organizational structure of most diplomatic missions, is - in many cases missing in the organizational structure of representative offices (but also other unofficial representations) of Taiwan. It may be assumed that the frequent absence of political departments at the unofficial representations of Taiwan is due to the fact that these representations - unlike the "standard" diplomatic missions - work in countries with which Taiwan does not have established diplomatic relations and, as a result, it only carries out political contacts (with these states) to a limited extent. The absence of political sections within some representative offices, however, may also be due to subjective worries relating to the "political incorrectness" of establishing such departments. The existence of a political section, i.e., a department that deals with political relations, in the organizational structure of Taiwan's representation might, under certain circumstances, be viewed as a visible demonstration of the fact that this representation participates not only in the performance of tasks in the area of economic or cultural relations but also in a political dialogue with the host state authorities. From that view, it might be possible to infer that the host state recognizes the representation of Taiwan as a partner for political dialogue, which can, in turn, be interpreted as a display of the host state's recognition of the Taiwanese authorities' political legitimacy. The existence of a political section at an unofficial representation of Taiwan could then be perceived as challenging the position of the PRC government as the sole legitimate representative of the whole of China and thus complicate the relations of the host country with the PRC.

From the viewpoint of legal standing, unofficial foreign representations of Taiwan do not have the status of diplomatic missions or consular offices, which means that privileges, immunities, or other advantages arising from the provisions of the Vienna Convention on Diplomatic Relations or the Vienna Convention on Consular Relations do not apply to them. In practice, however, the unofficial representations of Taiwan are - in some cases granted a certain scope of privileges and immunities, as a rule, based on a national legal regulation of the host state and/or a special bilateral treaty. For example, Australia grants to the Taiwanese representations, on the basis of its national legal regulations, in particular, Overseas Missions (Privileges and Immunities) Act 1995 and Taipei Economic and Cultural Office (Privileges and Immunities) Regulations 1998, a rather broad scale of privileges and immunities. These in relation to the representations (offices) include, e.g., inviolability of premises, property, documents, and archives, exemption from taxes, freedom of communication for official purposes, the right to use code for official communications, and the right to send and receive official documents by couriers having a standing equal to diplomatic couriers. In relation to the 
staff of the representations, they have, e.g., immunity from the criminal, civil, and administrative jurisdiction of the local authorities, immunity from arrest, search, and detention, and exemption from obligations to give evidence in judicial or administrative proceedings (Overseas Missions (Privileges and Immunities) Act 1995). The USA, too, grants a rather wide scale of privileges and immunities to the representations of Taiwan on the basis of the Agreement on Privileges, Exemptions and Immunities between the American Institute in Taiwan and the Taipei Economic and Cultural Representative Office in the USA. In accord with the provisions of this document, the representations of Taiwan in the USA enjoy privileges and immunities, which include, for instance, the inviolability of premises from forced entry and search, inviolability of archives and documentation, and exemption from local and federal taxes (with a few exceptions). The staff members of the representation of Taiwan in Washington are, in addition to these, also granted privileges and immunities in the form of exemption from criminal jurisdiction, exemption from the obligation to give evidence in criminal, civil, administrative, or other proceedings before the local authorities, as well as immunity from arrest and detention. The staff members of other representations of Taiwan in the USA are granted analogous privileges and immunities like the staff of the representation in the capital, but with limited scope, e.g., the immunity from arrest and detention only relates to minor offences for which they would be liable to a sentence of imprisonment of $<1$ year; the exemption from the obligation to give witness only covers particular cases (Agreement on Privileges, 2017). On the contrary, e.g., Germany does not grant Taiwan's representations or their staff any privileges, immunities, or other advantages at all (Embassy of the Federal Republic of Germany in Bratislava, pers. comm., February 17, 2017). As far as the representations of Taiwan in Slovakia and in the Czech Republic are concerned, they enjoy the same privileges and immunities as the consular offices led by career consular officers in accordance with the Vienna Convention on Consular Relations, but with a few exceptions, related to protocol and formal issues, e. g., they have no right to use the national flag and coat-of-arms outdoor (Taipei Representative Office in Bratislava, Representative, pers. comm., February 21, 2017).

As outlined above, from the formal and legal viewpoint, the staff of the unofficial representations of Taiwan does not enjoy diplomatic or consular status. The staff members of Taiwan's unofficial representations likewise do not use diplomatic or consular ranks, but instead, to express the hierarchical level of their particular functional positions, they use "civil" designations, typical rather of the business sphere, such as "senior assistant" or "deputy head". Similarly, in the naming of the individual positions within Taiwan's 
representations, the "traditional" diplomatic denominations are not used, such as the "economic attaché" or "cultural attaché", but instead we encounter "nondiplomatic" titles such as "head of economic department" or "head of cultural department". Otherwise, from a professional viewpoint, the staff members of Taiwan's unofficial representations are mostly career diplomats for whom work at such representations is part of their professional diplomatic career in Taiwan's Foreign Service, and they are employees of Taiwan's Ministry of Foreign Affairs.

The position of Taiwan's unofficial representations is also specific from the protocolar viewpoint and it differs from the position of diplomatic missions in several aspects. For example, when coming into office, the designated head of the unofficial representation of Taiwan does not present his/her credentials (or equivalent document) to the head of the host state ${ }^{20}$ and is not received by the minister of foreign affairs, as is customary in the case of the heads of diplomatic missions (Embassy of the Federal Republic of Germany in Bratislava, pers. comm., February 17, 2017; Taipei Representative Office in Bratislava, Representative, pers. comm., February 21, 2017). Likewise, members of the staff of Taiwan's unofficial representations are, as a rule, not regarded as members of the diplomatic or consular corps in their host state. As a result, they are not listed in the diplomatic or consular list of their host state, or if they are listed, it is not among the representatives of states, but in a separate section (e.g., in the Czech Republic, the members of the Taipei Economic and Cultural Office in Prague are not listed in the diplomatic list of the Czech Republic; in the Slovak Republic, the members of the Taipei Representative Office are listed in the diplomatic list among the accredited representatives of international organizations). In addition, Taiwan's unofficial representations and their heads are not allowed to use the national flag and coat-of-arms on their building and vehicles, as is customary in the case of diplomatic missions and their heads. On the other hand, there are also some features in the field of protocol that are common for Taiwan's unofficial representations and diplomatic missions. For example, the heads of Taiwan's unofficial representations are appointed by the President of the Republic of China as is customary in the case of ambassadors (Taipei Representative Office in Bratislava, Representative, pers. comm., February 21, 2017).

The personnel of Taiwan's unofficial representations is in most cases enabled, just like diplomatic representatives, to lead direct negotiations

\footnotetext{
20 Nor does the designated head of Taiwan's representation present the letter of cabinet to the minister of foreign affairs, as is customary in the case of heads of diplomatic missions in a capacity of chargé d'affaires en pied (lower diplomatic class).
} 
with the ministry of foreign affairs of the host state. The staff of Taiwan's representations is usually allowed to meet and negotiate with all workinglevel officials ${ }^{21}$ of the ministry of foreign affairs of the host state. However, all the negotiations conducted between Taiwan's unofficial representations and the ministries of foreign affairs of their host states are usually designated as "informal" (Liaison Office in South Africa in Taipei, pers. comm., February 23, 2017) or "at working level" (Embassy of the Federal Republic of Germany in Bratislava, pers. comm., February 17, 2017). We would like to add, however, that although contacts carried out by the unofficial representations of Taiwan in relation to the host states' ministries of foreign affairs may generally be designated as informal or working level, this informal or unofficial character may still have various different "hues" in the individual host states. In this respect, it is possible to observe a different approach from the individual ministries of foreign affairs to the disclosure of the existence and/or the forms of contacts with the representatives of the Taiwan representation. Whereas, e.g., the Ministry of Foreign Affairs of the Czech Republic publicly "confesses" to negotiations - even at the level of higher ministry representatives ${ }^{22}-$ with the representatives of the Taiwan representation and also proactively publicizes them through its own press releases, the Ministry of Foreign Affairs of the Slovak Republic provides no public information on the existence or forms of bilateral contacts with the representation of Taiwan (Ministry of Foreign and European Affairs of the Slovak Republic, pers. comm., February 7, 2017).

From the organizational viewpoint, all the unofficial representations of Taiwan belong under the administration, similar to its diplomatic missions and consular offices, of the Ministry of Foreign Affairs in Taipei, although the formal and legal status of these representations may not always seem to testify to this. In this regard, e.g., the Taipei Economic and Cultural Representative Office in the USA has the formal status of a nongovernmental institution but on the website of Taiwan's Ministry of Foreign Affairs, it is explicitly stated that its "operations... are under the direction of the Ministry of Foreign Affairs" (Ministry of Foreign Affairs, Republic of China 2014).

21 In the case of the Slovak Ministry of Foreign Affairs, e.g., the working-level officials include all officials of the ministry except for the minister and the state secretaries.

22 For example, on October 7, 2016, the Ministry of Foreign Affairs of the Czech Republic informed on its official website about the negotiations of the head of Taipei Economic and Cultural Office in Prague with the Deputy Minister of Foreign Affairs of the Czech Republic (See: Ministerstvo zahraničních věcí, 2016). 


\section{Conclusion}

We can conclude that Taiwan's diplomatic activities, from the point of view of their organization, institutional background, and the formal and protocolar regulations of their practical performance, do not markedly differ from the diplomatic activities carried out by most other states.

If we compare Taiwan's diplomatic activities with its paradiplomatic activities, we can find a number of differences, as well as similarities. Differences between the diplomatic and paradiplomatic activities of Taiwan may be observed in the area of their legal regulation, in particular, in the fact that the unofficial "paradiplomatic" representations of Taiwan are, as a rule, granted privileges and immunities only to a limited extent, due to their nondiplomatic status, and that too only in some host states. Other differences between Taiwan's diplomatic and paradiplomatic activities can be seen in the area of formal rules and protocolar policies applied in their practical performance. A special terminology is used for the designation of the unofficial "paradiplomatic" representations of Taiwan and their representatives, when, e.g., the heads of such representations are not officially addressed as "Ambassadors Extraordinary and Plenipotentiary" or "Consuls General" but as "representatives" or "director-generals" and the paradiplomatic representations themselves do not function under the official name of "embassy" or "consulate" but under various "alternative" names such as "Taipei Economic and Cultural Office" and so on. In the case of the heads of Taiwan's paradiplomatic representations, the host state is not notified of their appointment by means of credentials, as is the custom in the case of the heads of diplomatic missions. Likewise, the staff of the paradiplomatic representations does not use diplomatic ranks, nor are they considered to be a part of the diplomatic corps in the host state.

On the other hand, among the features common to both the diplomatic and paradiplomatic activities of Taiwan, we can list the fact that they are managed from a single joint headquarters, the Ministry of Foreign Affairs, and they are usually carried out by career diplomats, i.e., by professional members of Taiwan's Foreign Service. As another common feature of the diplomatic and paradiplomatic activities of Taiwan, we can also consider the fundamentally identical form of the inner organizational structure of the entities that participate in their work. The composition of the departments that we can observe within the organizational structure of Taiwan's paradiplomatic representations is very similar to that in diplomatic missions, also containing, e.g., a consular department.

On the basis of these considerations, we can conclude that the differences between the diplomatic and paradiplomatic dimensions of Taiwan's foreign 
activities are rooted mainly in their formal and protocolar aspect, whereas from the viewpoint of their organization and practical performance, these differences are minimal. We can also conclude that Taiwan's paradiplomatic activities are to a certain extent specific due to the fact that a number of their characteristic features, e.g., the existence of the consular dimension, resemble "traditional" diplomacy and do not possess a completely typical paradiplomatic character.

\section{References}

Agreement on Privileges, Exemptions and Immunities between the American Institute in Taiwan and the Taipei Economic and Cultural Representative Office in the United States, 4 February 2013. Accessed February 26, 2017. http://photos.state.gov/libraries/ait-taiwan/171414/aittecro-2013/20130204 - agmt-on-privileges-exemptions-immunities-english.pdf

Aguirre, Ińaki. 1999. "Making Sense of Paradiplomacy? An Intertextual Enquiry about a Concept in Search of a Definition." In Paradiplomacy in Action. The Foreign Relations of Subnational Governments, edited by Francisco Aldecoa, and Michael Keating, 185-209. London and Portland: Frank Cass Publishers.

Berridge, Geoff. 2010. Diplomacy. Theory and Practice. Fourth Edition. Houndmills, Basingstoke, Hampshire, New York: Palgrave Macmillan.

Berridge, Geoff, and James, Alan. 2003. A Dictionary of Diplomacy. Second Edition. Houndmills, Basingstoke, Hampshire, New York: Palgrave Macmillan.

Criekemans, David. 2010. "Regional Sub-State Diplomacy from a Comparative Perspective: Quebec, Scotland, Bavaria, Catalonia, Wallonia and Flanders.” In Regional Sub-State Diplomacy Today, edited by David Criekemans, 37-64. Leiden and Boston: Martinus Nijhoff Publishers.

Duchacek, Ivo. 1988. "Multicommunal and Bicommunal Polities and Their International Relations." In Perforated Sovereignties and International Relations. Trans-Sovereign Contacts of Subnational Governments, edited by Ivo Duchacek, Daniel Latouche, and Garth Stevenson, 3-28. New York and London: Greenwood Press.

Duchacek, Ivo. 1990. "Perforated Sovereignties: Towards a Typology of New Actors in International Relations." In Federalism and International Relations. The Role of Subnational Units, edited by Hans J. Michelmann, and Panayotis Soldatos, 1-33. New York: Oxford University Press.

Drulák, Petr, Königová, Lucie, and Kratochvíl, Petr. 2004. "Jak si stojí česká paradiplomacie?" ["How does the Czech paradiplomacy look?"]. Policy Paper ÚMVDuben: 1-5.

Hubinger, Václav. 2006. Encyklopedie diplomacie. [An Encyclopedia of Diplomacy]. Praha: Libri.

"Joint Communiqué of the Governments of the United Kingdom of Great Britain and Northern Ireland and of the People's Republic of China on an exchange of Ambassadors." March 13, 1972 in Beijing. Translation according to Chinese Version. In China-Britain, edited by G. Changjian, 2094. China Intercontinental Press, 2004. 


\section{Journal of Nationalism, Memory \& Language Politics 11(1)}

Kleiner, Jürgen. 2010. Diplomatic Practice. Between Tradition and Innovation. Singapore: World Scientific Publishing.

Kočnerová, Mária, and Marenčáková, Tatiana. 2014. "Č́nsko-americké vztahy počas administratívy Georgea Busha." [“Chinese-American Relations under George Bush Administration”]. In Aktuálne výzvy svetovej politiky (recenzovaný vedecký zbornik), edited by Tatiana Tökölyová, 3-16. Bratislava: Central European Education Institute.

Kuznetsov, Alexander S. 2015. Theory and Practice of Paradiplomacy. Subnational Governments in International Affairs. London, New York: Routledge.

McMillan, Samuel L. 2012. The involvement of state governments in U. S. foreign relations. New York: Palgrave Macmillan.

Ministerstvo zahraničních věcí ČR, Ekonomická diplomacie. 2016. "Náměstek Martin Tlapa přijal na MZV vedoucího Tchajpejské hospodářské a kulturní kanceláře v Praze Joey Wanga”. [Deputy Minister Martin Tlapa received at the Foreign Ministry the Head of the Taipei Economic and Cultural Office in Prague Joey Wang]. Last modified October 7. http://www.mzv.cz/ekonomika/cz/udalosti/namestek_martin_tlapa_prijal_na_mzv.html

Ministry of Foreign Affairs, Republic of China. 2016. "ROC Embassies and Missions Abroad." Last modified 2016. http://www.roc-taiwan.org/portalOfDiplomaticMission_en.html

Ministry of Foreign Affairs, Republic of China. 2014. "Structure and Functions." Last modified 2014. http://www.mofa.gov.tw/en/Organization.aspx?n=71C67D43CEB5EF3F\&sms= A8F1FA2030B6089B\#hash696218F4A79ADCDC

Overseas Missions (Privileges and Immunities) Act 1995. No. 57, 1995 as amended. Compilation start date: 29 June 2013, Includes amendments up to: Act No. 103, 2013. Accessed February 24, 2017. https://www.legislation.gov.au/Details/C2013C00423

Permanent Mission of the Separate Customs Territory of Taiwan, Penghu, Kinmen and Mastu to the World Trade Organization. 2016. "History." Last modified December 21. http:// www.roc-taiwan.org/wto_en/post/10.html

"Proclamation of the Central People's Government of the PRC," October 01, 1949, History and Public Policy Program Digital Archive, Renmin ribao (People's Daily), October 2, 1949. English translation from The Writings of Mao Zedong, 1949-1976, Volume I, September 1949-December 1955, edited by Michael Y.M. Kau, 10-11. New York: M.E. Sharpe, 1986. http://digitalarchive.wilsoncenter.org/document/121557

Rawnsley, Gary D. 2000. Taiwan's Informal Diplomacy and Propaganda. New York: Palgrave Macmillan.

Rosputinský, Peter. 2015. Vybrané otázky diplomatického práva. [Selected Questions of Diplomatic Law]. Banská Bystrica: Belianum. Vydavatel'stvo Univerzity Mateja Bela v Banskej Bystrici.

Taipeh Vertretung in der Bundesrepublik Deutschland. Buero Muenchen. 2015. "Der Service." ["The Services"]. Last modified September 20. http://www.roc-taiwan.org/demuc_ $\mathrm{de} /$ post/8.html

Taipei Economic and Cultural Office in Auckland. 2016. "About us." Last modified May 17. http://www.roc-taiwan.org/nzakl_en/post/246.html

Taipei Economic and Cultural Office in Chicago. 2016. "About TECO.” Last modified July 8. http://www.roc-taiwan.org/uschi_en/post/6.html 
Taipei Economic and Cultural Office in New Zealand. 2017. "An Introduction of Taipei Economic and Cultural Office in New Zealand.” Last modified February 27. http://www. roc-taiwan.org/nz_en/post/299.html

Taipei Economic and Cultural Office (Privileges and Immunities) Regulations 1998. Statutory Rules 1998 No. 300 as amended made under the Overseas Missions (Privileges and Immunities) Act 1995. Compilation prepared on 29 August 2002 taking into account amendments up to SR 2002 No. 197. Accessed February 26, 2017. https://www.legislation.gov.au/Details/ F2004C00756

Tóth, Ludovít. 2008. "Diplomacia a diplomatické vztahy." ["Diplomacy and Diplomatic Relations"]. In Úvod do diplomacie, 9-19. Bratislava: Ekonóm.

Veselý, Zdeněk. 2014. Diplomacie: (teorie-praxe-dèjiny). 2. upravené vydání. [Diplomacy: (Theory-Practice-History). 2nd Revised Edition]. Plzeň: Vydavatelství a nakladatelství Aleš Čeněk.

Widmer, Paul. 2014. Diplomatie. Ein Handbuch. [Diplomacy. Handbook]. Zürich: Verlag Neue Zürcher Zeitung.

Wolff, Stefan. 2007. "Paradiplomacy: Scope, Opportunities and Challenges." The Bologna Center Journal of International Affairs Spring: 141-50.

World Trade Organization. Document No. WT/L/433, 23 November 2001, (01-5986). Accession of the Separate Customs Territory of Tawain, Penghu, Kinmen and Matsu. Accessed January 29, 2017. https://docs.wto.org/dol2fe/Pages/FE_Search/FE_S_S009-DP.aspx?language=E $\&$ CatalogueIdList=35625,33346,18756,37254,17243\&CurrentCatalogueIdIndex $=1 \&$ Full TextHash= 